\title{
REPOSISI PRAKTIK EKONOMI ISLAM : STUDI KRITIS PRAKTIK EKONOMI ISLAM DI INDONESIA
}

\author{
Islamic Economics Practice Repotition: \\ Critical Study on Islamic Economics Practice in Indonesia
}

\author{
Azwar Iskandar \\ Badan Pendidikan dan Pelatihan Keuangan \\ Email : azwar.iskandar@gmail.com \\ Khaerul Aqbar \\ Sekolah Tinggi Ilmu Islam dan Bahasa Arab (STIBA) Makassar \\ Email : khaerul@stiba.ac.id
}

\begin{abstract}
Keywords :
ABSTRACT

economy, islam, shariah, critical, indonesia

The study attempts to analyse several things that become critical points faced by Indonesia sharia economic practices that cause its application is less developed. This study use descriptive-qualitative approach with critical methode and library research. This research found that: (1) Sharia economy is not only financial sector but also includes the industrial sector, trade and various other real sectors; (2) Naming 'syariah bank' is misleading. The appropriate nomenclature is not 'syariah bank' but syariah financial institution; (3) The attention of economic practioner both conventional and shariah, until now, only focused on achieving profit, protect loss, and welfare; (4) In the concept of Islam, the loss that faced by buman is caused apart from buman factor and environment, it can be also caused by $\sin$ of business operators; (5) all moslem people and experts should not only concern on method of gain profit, but also encourage and promote people widely to commit the shariah rules in spending money; (6) The special education of syariab banking is needed by including it in universities and schools curriculum.
\end{abstract}

\section{Kata kunci :} ABSTRAK

ekonomi, islam, syariah, kritik, indonesia

Penelitian ini bertujuan untuk menganalisis beberapa hal yang menjadi
poin kritis yang dihadapi oleh praktik ekonomi syariah Indonesia yang
mengakibatkan penerapan ekonomi syariah di Indonesia kurang
berkembang. Penelitian ini menggunakan pendekatan kualitatif-
deskriptif dengan metode studi kritis dan studi literatur (library research).
Penelitian ini menemukan bahwa: (1) Ekonomi Islam bukan hanya
sektor finansial, akan tetapi juga mencakup sektor industri, perdagangan
dan berbagai sektor riil lainnya; (2) Penamaan Bank Syariah adalah salah
kaprah. Nomenklatur yang lebih tepat bukanlah Bank Syariah akan
tetapi Lembaga Keuangan Syariah; (3) Perhatian para praktisi ekonomi
konvensional atau syariah, hingga saat ini, hanya terpusat pada upaya
mewujudkan keuntungan, menghindarkan kerugian, dan memeratakan
kesejahteraan; (4) Dalam konsep Islam, kerugian yang dialami manusia,
selain karena faktor manusia dan lingkungan, juga dapat diakibatkan
oleh dosa para pelaku usaha; (5) Sepantasnya bila umat Islam dan para
pakar ekonomi Islam tidak hanya mencurahkan perhatian pada metode
meraup keuntungan, tetapi juga menggalakkan dan menyeru masyarakat
Islam secara luas untuk mengindahkan syariat Islam dalam hal
pembelanjaan harta kekayaan; (6) Dibutuhkan pendidikan ilmu
perbankan Syariah yang memadai dengan memasukkan sistem ekonomi
Islam ke dalam kurikulum universitas dan sekolah.




\section{PENDAHULUAN}

Seiring dengan berjalannya waktu, kesadaran umat Islam akan pentingnya kembali kepada pangkuan agama semakin terasa kuat dan membulat. Demikianlah dinamika kehidupan umat Islam sepanjang sejarah. Pasang-surut ini selaras dengan pasang-surut iman dan ketakwaan yang hadir di tengah umat. Sungguh benar sabda Rasulullah, Muhammad shallallāhu 'alayhi wa sallam, bahwa (artinya), "Sunggub keimanan itu dibuat di dalam diri tiap kalian seperti dibuatnya pakaian. Maka mintalah kepada Allah agar memperbaharui keimanan kalian." Begitulah sunnatullāh, bahwa kehidupan yang kita rasakan, dalam beberapa kesempatan dan keadaan, iman akan terasa bertambah, dan di lain kesempatan kondisi iman akan terasa menurun.

Sejarah perjalanan umat Islam di negeri kita adalah salah satu buktinya. Seruan untuk menjadikan syariat Islam sebagai asas kehidupan dalam segala aspeknya terus bergemuruh dan menguat hari ini. Tidak heran bila saat ini segala yang berembel-embel Islam atau syariat telah diminati dan bahkan laku dijual ke masyarakat. Dimulai dari partai islam, sekolah islam, rumah sakit islam, perusahaan islam, dan lain sebagainya. Di antara sektor yang menggeliat dengan kuat ialah sektor perekonomian dan/atau keuangan. Geliat di sektor ini kemudian memunculkan fenomena ramainya bentuk-bentuk sistem dan model interaksi ekonomi dan keuangan, seperti perbankan syariah, asuransi syariah, pegadaian syariah dan lain sebagainya.

${ }^{1}$ HR. al-Hakim dalam al-Mustadrak I/4. Silsilah asShahihah no.1585. Al-Haitsami berkata di dalam Majma'
Dalam tataran teknis, tak asing lagi bagi kita berbagai istilah yang biasa digunakan oleh para ulama ahli fikih dahulu, seperti mudārabah, ijārah, syarikah, riba, istisna' dan lain sebagainya. Konsep ekonomi dan keuangan berbasis syariah dewasa ini telah tumbuh secara pesat, diterima secara universal dan diadopsi tidak hanya oleh negara-negara Islam di kawasan Timur Tengah saja, tetapi juga oleh berbagai negara di kawasan Asia, Eropa, dan Amerika. Hal tersebut ditandai dengan didirikannya berbagai lembaga keuangan syariah dan diterbitkannya berbagai instrumen keuangan berbasis Syariah (Iskandar, 2014).

Lebih jauh, lembaga-lembaga ekonomi yang berbasiskan Syariah, lahir dan meramaikan panggung perekonomian nasional disebabkan karena adanya krisis yang berkepanjangan sebagai akibat atau buah kegagalan sistem moneter kapitalis. Sejak berdirinya Bank Muamalat sebagai pelopor bank yang menggunakan sistem syariah pada tahun 1991 dan diikuti dengan diterbitkannya Undang-Undang (UU) Nomor 10 Tahun 1998 Tentang Perubahan Atas Undang-Undang Nomor 7 Tahun 1992 Tentang Perbankan yang memungkinkan perbankan menjalankan dual banking system, kini banyak bermunculan bankbank syariah, baik yang murni menggunakan sistem tersebut maupun baru pada tahap membuka Unit Usaha Syariah (UUS) atau divisi usaha syariah.

Dalam kurun waktu kurang lebih 28 tahun, hingga akhir Juli 2019, perbankan syariah secara keseluruhan saat ini terdiri dari 14 Bank Umum

az-Zawäid I/52 : diriwayatkan oleh at-Thabarani dalam kitab al-Kabîr dan sanadnya hasan. 
Syariah, 374 Unit Usaha Syariah dan 165 Bank Pembiayaan Rakyat Syariah (BPRS) (Otoritas Jasa Keuangan, 2019). Penambahan kuantitas tersebut kemudian diimbangi oleh penetrasi jangkauan layanan. Sebelumnya, pada bank maupun unit syariah hanya boleh melayani calon nasabah di kantor cabang syariah atau kantor cabang pembantu. Namun sejak office channeling yang didasari Peraturan Bank Indonesia Nomor 8/3/PBI/2006 dan berlaku efektif mulai Mei 2007, pelayanan jasa financing seperti pembukuan rekening, setor, transfer, kliring dan tarik tunai bisa dilakukan di cabang bank umum yang mempunyai unit syariah. Dengan penerapan office channeling ini, akselerasi pertumbuhan bisa terealisasi (Lubis, 2016). Perbankan syariah sebagai bagian dalam industri perbankan nasional, dengan karakteristiknya yang khusus sesungguhnya memiliki potensi yang besar untuk memberikan kontribusi dalam mewujudkan inklusifitas keuangan nasional (Umar, 2017; Iskandar dan Possumah, 2018).

Seluruh upaya dan perjuangan sampai pada titik ini merupakan suatu hal yang patut untuk disyukuri. Meski demikian, kekurangan dan kelemahan sistem yang telah ada sebagai sebuah produk ciptaan manusia pasti menyisakan celah dan kekurangan yang patut untuk dikritisi dan diperbaiki. Hal ini membutuhkan sikap seluruh eleman bangsa di setiap masa, dalam rangka penyempurnaan dan perbaikan di masa-masa yang akan datang.

Sikap kritis bertujuan untuk meneruskan keberhasilan dan memangkas kekurangan dan kesalahan. Rasulullah, Muhammad shallallāhu 'alayhi wa sallam, bersabda (artinya), "Setiap anak Adam sering melakukan kesalaban, dan sebaik-baik orang yang bersalah adalab orang yang bertaubat (kembali kepada kebenaran)." Sudah sepantasnya jika setiap komponen umat Islam senantiasa berkontribusi secara konstruktif dalam perjuangan penerapan syariat Allah Ta'āla di segala aspek kehidupan, tidak terkecuali pada aspek ekonomi umat. Apalagi dalam praktik di lapangan, berbagai praktik ekonomi dan/atau keuangan syariah telah menuai banyak kecaman dan kritikan dari para ilmuwan muslim sendiri.

Sebut saja misalnya, mereka berpendapat bahwa bank-bank syariah dalam menjalankan kegiatan usahanya, ternyata bukannya meniadakan bunga dan membagi resiko, tetapi tetap mempertahankan praktek pembebanan bunga, namun dengan label Islam (Rahmawaty, 2007). Dalam tataran teknis, Syu'aibun (2014) misalnya, menemukan bahwa terdapat deviasi atau penyimpangan akad mudārabah dalam aplikasinya pada sistem perbankan Syariah. Rusydi (2016) menemukan bahwa berbagai kesamaan konsep bank syariah dengan bank konvensional yang membuatnya memang tidak bisa selaras denga ketentuan syariah serta banyaknya penyimpangan dalam peraktek perbankan syariah diantaranya yang berhubungan dengan akad muḍarabah.

Selain itu, hadirnya berbagai regulasi pemerintah terkait implementasi ekonomi Syariah di Indonesia, seperti

2 HR. Ahmad (III/198), At-Tirmidzi (no. 2499), Ibnu Majah (no. 4251) dan Al Hakim (IV/244). Lihat Sahìh Jàmi'us-Saghìr (no. 4515), dari sahabat Anas. 
UU Nomor 10 Tahun 1998, UU Nomor 38 Tahun 1999 tentang Pengelolaan Zakat dan Keputusan Mahkamah Agung Nomor 581 Tahun 1999 tentang Pengelolaan Zakat serta UU No. 3 Tahun 2006 tentang Pengadilan Agama dengan kewenangan kompetensi yang bertambah untuk menyelesaikan kasuskasus yang terkait bisnis syariah (Dahlan, 2008), menyiratkan pesan penting dan tegas bahwa studi mengenai sistem ekonomi dan/atau keuangan syariah menjadi hal yang urgen karena telah diimplementasikan secara luas dan dilindungi oleh UU. Kebutuhan akan studi atau kajian tersebut terus dibutuhkan dalam rangka memberikan penguatan terhadap sistem yang telah berjalan sehingga menjadi lebih baik dan sekaligus mengklarifikasi bahwa sistem ekonomi yang dijalankan tidak melenceng dari asas-asas normatif dan Syariah.

Berangkat dari hal tersebut di atas, penulis bermaksud untuk memberikan andil dalam meluruskan dan mengoreksi upaya penerapan syariat Islam dalam perekonomian umat dengan melakukan sebuah penelitian dan kajian kritis terhadap fenomena tersebut. Beberapa fakta perkembangan ekonomi Islam yang telah berjalan di masyarakat, terdapat beberapa hal yang menurut penulis dapat menjadi sebab penerapan ekonomi syariah di Indonesia terkesan berjalan di tempat. Paradigma dan pendekatan-pendekatan normatif ekonomi Islam yang ada di tengah umat, perlu dibawa menuju sistem ekonomi yang rasional dan luhur sebagaimana semangat dan value yang diusung oleh sistem ekonomi Islam itu sendiri.
Oleh karena itu, permasalahan yang mengemuka dan hendak dijawab pada penelitian ini adalah :

1. Hal-hal apa saja yang perlu diluruskan dan masih membutuhkan perhatian lebih dalam untuk perbaikan dan penyempurnaan praktik ekonomi Islam di Indonesia?

2. Apa solusi atau saran yang dapat ditawarkan untuk mengatasi hal-hal tersebut?

Untuk menjawab permasalahan tersebut, penelitian ini dilakukan dengan tujuan untuk :

1. Menganalisis beberapa hal yang menjadi poin kritis yang dihadapi oleh praktik ekonomi syariah Indonesia yang mengakibatkan penerapan ekonomi syariah di Indonesia kurang berkembang. Perlu digarisbawahi bahwa kritik atau kelemahan yang dimaksud pada penelitian ini bukanlah pada perkara nilai yang terkandung di dalam konsep ekonominya, tetapi lebih pada hambatan pada implementasinya dalam realitas masyarakat dan umat;

2. Menganalisis solusi atau saran yang dapat diberikan dalam mengatasi hal-hal yang menjadi poin kritis yang dihadapi oleh praktik ekonomi syariah Indonesia sehingga penerapan ekonomi syariah di Indonesia kurang berkembang.

Penelitian ini menggunakan pendekatan kualitatif-deskriptif dengan metode studi kritis dan riset kepustakaan (library research). Penelitian dengan metode atau paradigma kritis mengungkapkan dan menganalisis realitas sosial dengan mempersoalkan ketimpangan relasi sosial yang ada. Penelitian kritis ditopang oleh 
perspektif teori kritis dengan asumsiasumsi yang dikonstruksinya (Halik, 2018). Pendekatan penelitian kritis lebih jauh lagi, yaitu berorientasi pada pemecahan masalah dan perubahan sosial (Hanurawan, 2010). Sementara riset kepustakaan (library research) pada penelitian ini mengunakan jenis dan sumber data sekunder yang diperoleh dari hasil penelitian, artikel dan bukubuku referensi yang membahas topik yang berkaitan dengan tema penelitian (Iskandar dan Aqbar, 2019).

Sejauh pengamatan penulis, penelitian terkait studi kritis atas paradigma dan implementasi ekonomi Islam berdasarkan prinsip-prinsip pokok agama, belum banyak dilakukan. Penelitian-penelitian terdahulu seperti yang dilakukan oleh Rahmawaty (2007), Sulaiman (2014), Syu'aibun (2014), dan Lubis (2016) hanya melihat dan mengkritisi salah satu akad dalam implementasi ekonomi Islam dengan ruang lingkup yang cenderung lebih sempit karena tidak melihatnya dari sudut pandang atau paradigma yang lebih mendasar. Sementara penelitian ini membahas poin-poin kritik terhadap implementasi ekonomi Islam dari sudut pandang atau paradigma yang lebih mendasar.

\section{PEMBAHASAN}

Sebagaimana yang telah dijelaskan di atas, beberapa fakta perkembangan ekonomi Islam yang telah berjalan saat ini, terdapat beberapa hal yang perlu untuk diluruskan. Paradigma dan pendekatan-pendekatan normatif ekonomi Islam yang berjalan saat ini, perlu dibawa menuju sistem ekonomi

https://www.cnnindonesia.com/ekonomi/201909110343 28-78-429312/knks-sebut-pertumbuhan-pangsa-pasar- yang rasional dan luhur sebagaimana semangat dan value yang diusung oleh sistem ekonomi Islam sejak awal. Berikut beberapa hal yang patut untuk diperbaiki sebagai bentuk kritikan terhadap praktik dan praktisi ekonomi Syariah.

\section{Dominasi Ekonomi Syariah pada Sektor Keuangan}

Apabila kita bertanya kepada masyarakat luas tentang apa yang pertama kali terbayang di benak mereka setiap kali mendengar kata 'ekonomi syariah'? Kemungkinan besar hal yang terbetik pertama kali di benak kebanyakan dari mereka tentang ekonomi syariah adalah perbankan syariah, asuransi syariah, obligasi syariah dan semacamnya. Jika pun melebar, kemungkinan yang berikutnya adalah tidak jauh-jauh dari seputar masalah zakat, infak, sedekah, dan wakaf. Tidak heran bila Komite Nasional Keuangan Syariah (KNKS) menilai kondisi industri keuangan syariah di Indonesia masih jalan di tempat. Terbukti, data Otoritas Jasa Keuangan (OJK) terbaru menyebutkan pangsa pasar keuangan syariah baru mencapai 8,69 persen dari total pasar keuangan nasional. Bahkan secara khusus, Direktur Pengembangan Ekonomi Syariah dan Industri Halal KNKS, Afdhal Aliasar, merincikan dari jumlah tersebut, pangsa pasar perbankan syariah tercatat hanya 5,94 persen. Sedangkan sisanya atau sebesar 2,75 persen merupakan pangsa pasar non perbankan syariah. ${ }^{3}$

Perhitungan di atas hanyalah berdasarkan pada jumlah dana

keuangan-syariah-stagnan. Diakses pada tanggal 10 Oktober 2019. 
masyarakat yang dikelola oleh perbankan syariah. Kita melupakan berbagai praktik ekonomi Syariah di luar sektor keuangan tersebut seperti di pasar tradisional, pertanian, industri dan lainnya. Gambaran sempit tentang ekonomi Islam yang ada di benak kebanyakan umat Islam ini, bisa jadi merupakan salah satu alasan yang menjadikan perhatian para praktisi ekonomi Islam saat ini hanya berkutat pada dunia perbankan atau sektor finansial.

Padahal sejatinya, ekonomi Islam bukan hanya sektor finansial, akan tetapi juga mencakup sektor industri, perdagangan dan berbagai sektor riil lainnya. Jika kita melihat lebih jauh, niscaya kita akan mendapati bahwa sektor finansial justru akan senantiasa bergantung pada sektor-sektor riil. Bila demikian adanya, berbagai perjuangan dan upaya yang dicurahkan hanya akan menemui jalan buntu. Sebab, sektor keuangan, sejatinya tidak dibenarkan untuk terjun langsung ke sektor riil atau bisnis praktis yang dapat menghasilkan keuntungan halal menurut UU Nomor 10 tahun 1998. Hal ini dikarenakan uang yang merupakan faktor utama sektor finansial, adalah alat untuk menjalankan roda ekonomi dan bukan sebagai objek perekonomian. Objek sejati perekonomian ialah barang atau jasa, yang selanjutnya dinilai dengan uang, dan bukan uang dinilai dengan uang. Apabila uang yang notabene adalah alat transaksi dan niaga dijadikan sebagai objek utama niaga, maka yang terjadi adalah riba, berbagai tindak spekulasi dan berbagai kekacauan.
Tidak heran bila berbagai kalangan mengkhawatirkan terjadinya over likuidasi pada sektor keuangan syariat yang ada. Di mana Dana Pihak Ketiga (DPK) mengalir begitu deras, akan tetapi sektor keuangan syariat tidak kuasa menyalurkannya kepada sektor riil. Kekhawatiran ini cukup mendasar, sebab keuntungan yang didapat oleh kebanyakan sektor keuangan syariat hanyalah melalui penyaluran dana, dan bukan dari hasil niaga nyata. Kenyataan-kenyataan ini menyadarkan kita bahwa para pelaku atau praktisi ekonomi Islam hendaknya segera memusatkan perhatian dan perjuangan mereka pada sektor industri, perniagaan praktis, sektor riil dan yang semisial. Dengan demikian, mereka benar-benar menghasilkan keuntungan dari perniagaan nyata dan bukan dari mempertukarkan uang dengan uang. ${ }^{4}$

\section{Penamaan Bank Syariah yang Keliru}

Penamaan Bank Syariah sedari awal adalah salah kaprah. Nomenklatur yang lebih tepat bukanlah Bank Syariah akan tetapi Lembaga Keuangan Syariah. Mengapa demikian?

Alasan yang pertama, seperti yang kita ketahui bahwa bank bersifat profit oriented murni, sehingga dalam pelaksanaannya bank dituntut untuk selalu menaikkan keuntungan dari waktu ke waktu. Keuntungan tidak boleh tetap atau bahkan turun, sebab jika demikian, bank tersebut terancam akan ditutup. Sedangkan pada lembaga keuangan Syariah, orientasi aslinya adalah mengutamakan asas tå'âwun atau berlandaskan prinsip saling tolong

4 https://pengusahamuslim.com/2158-mengkritisi-parapraktisi-ekonomi-syariah-seri-2.html. Diakses pada tanggal 10 Oktober 2019. 
menolong diantara sesama. Hal ini diutamakan di atas kepentingan mencari keuntungan. Dalam artian, boleh mencari keuntungan sekedarnya dengan tetap mengutamakan prinsip tolong-menolong terhadap sesama. Namun pada kenyataanya yang terjadi justru sama saja, baik bank konvensional maupun bank syariah sama-sama mengejar keuntungan sebanyak-banyaknya sehingga kurang memperhatikan nasib customer. Sehingga penamaan bank kurang cocok dan lebih pas dengan istilah Lembaga Keuangan Syariah (LKS).

Sebenarnya orientasi tersebut bermula dari adanya perbedaan permasalahan dalam ekonomi konvensional dan ekonomi syariah. Permasalahan ekonomi konvensional adalah terbatasnya alat pemenuhan kebutuhan yang tidak sebanding dengan kebutuhan manusia yang tak terbatas, sedangkan pada ekonomi syariah masalah ekonomi ada pada distribusi kekayaan yang tidak merata. Hal ini disadari berdasarkan realitas bahwa ekonomi konvensional pada hakikatnya adalah hasil analisa akal pikir manusia yang melahirkan teori dan cara agar seseorang mendapatkan keuntungan dan modal yang sebanyak banyaknya. Efek yang ditimbulkan dari pola pikir ini adalah seseorang cenderung egois dan kurang memperhatikan nasib orang lain. Berbeda dengan ekonomi syariah yang hakikatnya adalah ajaran ketuhanan yang dituangkan dalam Alquran dan Hadis yang sangat menekankan moralitas yang baik, memperhatikan nasib tetangga dan saudara, mendahulukan kepentingan orang lain, meolong terhadap sesama dan lain sebaginya.
Alasan yang kedua adalah terkait dengan tugas dan wewenang. Pada dasarnya tugas bank berdasarkan UU Nomor 10 tahun 1998, diantaranya adalah menghimpun dana dari masyarakat, memberi kredit, menyalurkan pembiayaan, menyediakan tempat penyimpanan dan mentransfer uang. Apabila merujuk pada regulasi tersebut maka sesungguhnya tidak ada masalah dengan penamaan bank Syariah, karena aktivitas yang dilakukan oleh bank syariah sudah sesuai dengan koridornya.

Namun jika kita melihat pada larangan yang diberlakukan untuk perbankan, yakni bahwasannya bank tidak boleh menjalankan bisnis riil di luar sektor keuangan, maka penamaan bank syariah menjadi bermasalah. Hal ini karena bank sama sekali tidak boleh melakukan aktifitas bisnis atau perniagaan nyata. Sedangkan yang dilakukan oleh Bank Syariah -dalam hal ini adalah pembiayaan melalui produkproduknya, seperti akad murābahah, akad mudārabah, akad salām, akad istisna', akad ijärah, dan lainnya-, semua itu adalah bentuk dari tijarah atau perdagangan. Ini tidak sesuai dengan regulasi yang ada.

Di sinilah letak kekeliruan yang perlu diluruskan. Pada praktiknya, seluruh bank syariah melakukan bisnis nyata yang sebenarnya kurang sesuai dengan prinsip dan larangan yang berlaku untuk bank pada umumnya. Penamaan yang lebih sesuai adalah lembaga keuangan syariah. Alasannya sederhana, LKS Syariah diperbolehkan melakukan aktivitas jual beli atau bisnis riil atau bisinis di sektor selain keuangan. Akan tetapi, menurut hemat penulis, penamaan ini juga akan 
menjadi bias, membingungkan dan akan tumpang tindih, karena tidak akan ada perbedaan antara lembaga keuangan syariah dalam bentuk bank dan non bank, yang berpengaruh terhadap siapa atau pihak mana yang memiliki otoritas dan lebih berhak dalam mengawasi aktivitas lembaga keuangan tersebut, apakah OJK atau Kementerian Koperasi.

Memang nama sekedar istilah saja, namun nama menjadi penting jika dikaitkan dengan peraturan untuk menjamin ketertiban dan jaminan terhadap hak dan kewajiban masingmasing pihak yang terkait. Adapun menurut penulis, kaidah "al-'ibratu bi umūmi al-lafzi là bikhusūsisi alsababi" $^{5}$ yang bermakna bahwa keumuman makna lafaz lebih didahulukan daripada kekhususan sebab (Mahmuddin, 2016) adalah kaidah yang patut dikedepankan. Dalam hal ini, Bank Syariah pada dasarnya telah memenuhi prinsipprinsip umum bank, meskipun dalam penerapannya bank melakukan bisnis di luar sektor keuangan yang mana bertujuan agar akad-akad yang ada dalam bank syariah menjadi halal hukumnya (adanya underlying asset).

\section{Replikasi Konsep 'Ekonomi Qarun'}

Perhatian para praktisi ekonomi konvensional atau syariah, hingga saat ini, hanya terpusat pada upaya mewujudkan keuntungan, menghindarkan kerugian, dan memeratakan kesejahteraan. Bahkan, ada yang bermimpi untuk

5 Terdapat pada Kitab Mandzūmah Usūilil Fiqhi wa Qawāidihi, bait ke 100-101, oleh Muhammad bin Shalih Al-'Utsaimin.

${ }^{6}$ https:// tafsirq.com/43-az-zukhruf/ayat-32\#tafsirjalalayn. menghapuskan kemiskinan hingga betul-betul habis. Impian ini sejatinya bertentangan dengan ketentuan Allah Ta'āla. Dalam sebuah ayat-Nya, Allah Ta'āla berfirman (artinya), "Apakah mereka yang membagi-bagi rahmat Rabbmu? Kami telab menentukan antara mereka, pengbidupan mereka dalam kebidupan dunia, dan Kami telah meninggikan sebagian mereka atas sebagian yang lain beberapa derajat, agar sebagian mereka dapat mempergunakan sebagian yang lain. Dan rabmat Rabbmu lebih baik dari segala sesuatu yang mereka kumpulkan." (QS. Az-Zukhruf:32).

Ayat tersebut telah menegaskan bahwa kaya dan miskin adalah dua kelompok yang akan selalu ada hingga akhir zaman. Dalam Tafsir Jalalayn disebutkan maksud ayat ini bahwa, "Kami telah menentukan antara mereka penghidupan mereka dalam kehidupan dunia, Kami jadikan sebagian dari mereka kaya dan sebagian lainnya miskin, dan Kami telah meninggikan sebagian mereka dengan diberi kekayaan atas sebagian yang lain beberapa derajat, agar sebagian mereka dapat mempergunakan golongan orang-orang yang berkecukupan (sebagian yang lain) atas golongan orang-orang yang miskin (sebagai pekerja). ${ }^{6}$

Banyak praktisi ekonomi Syariah melalaikan hubungan rezeki dengan Allah Ta'āla. Menurut mereka, Singapura, Inggris, dan berbagai negara kafir lainnya telah lebih dahulu menjadi pusat ekonomi Islam dibanding Indonesia. ${ }^{7}$ Padahal, tidak dapat diragukan bahwa negara-negara

http://majalahekonomisyariah.com/index.php/web/new s/index/2/125320961. 
tersebut jauh dari dasar utama ekonomi syariat Islam ini. Apalah gunanya keuntungan besar bila para pelaku ekonomi jauh dari pijakan dan dasar ini? Keuntungan besar dan kesuksesan bisnis di dunia tidak cukup sebagai bukti bahwa sistem yang diterapkan telah selaras dengan syariat Islam. Keuntungan yang besar bisa saja dicapai oleh orang-orang yang tidak beriman kepada Allah Ta'āla, dan bahkan menerapkan konsep yang nyata-nyata bertentangan dengan agama Islam.

Perlu diingat bagaimana kisah Qarun; simbol saudagar sukses, tetapi karena konsep ekonominya tidak didasari oleh keimanan kepada Allah, maka ia menanggung kebinasaan dunia dan akhirat. Allah mengisahkannya dalam firman-Nya (artinya), "Qarun berkata, 'Sesunggubnya, aku mendapatkan harta kekayaan itu banya karena kecerdasanku.' Dan apakah ia tidak mengetabui babwasanya Allab sunggub telah membinasakan umat-umat sebelumnya yang lebih kuat daripadanya dan lebih banyak kumpulan hartanya?" (QS. AlQashash:78)

Keimanan ini adalah syarat utama agar suatu sistem atau konsep dapat dinyatakan sebagai "syariat Islam". Secara lahir, bisa saja dua amalan serupa, tetapi pada hakikatnya, dua amalan itu sangat berbeda. Dalam sebuah Hadis yang diriwayatkan oleh Bukhari dan Muslim, sahabat Abu Musa rạiliyallāhu 'anhu mengisahkan, "Ada seorang lelaki yang menemui Rasulullah shallallāhu 'alayhi wa sallam, lalu ia bertanya, 'Ada seseorang yang berjuang, hanya karena ingin mendapatkan harta rampasan perang.
Ada lagi yang berjuang demi popularitas, dan ada pula yang berjuang agar orang lain menyaksikan keberaniannya di medan perang. Siapakah dari mereka yang disebut 'berjuang di jalan Allah'?' (Menjawab pertanyaan ini), Rasulullah shallallāhu 'alayhi wa sallam bersabda, 'Barang siapa yang berjuang demi menjadikan bukum Allah menjadi berjaya, maka ialah pejuang di jalan Allah." "s

Dari penjelasan-penjelasan di atas, pertanyaan yang muncul kemudian adalah, masih layakkah bagi umat Islam, terlebih para pakar dan praktisi ekonomi Islam, mengganggap bahwa beberapa konsep negara kafir yang tampak serupa dengan syariat Islam itu lebih baik? Apakah sama antara orang yang tidak mencuri karena tidak memiliki kesempatan dengan orang yang tidak mencuri karena takut kepada Allah? Inilah beberapa pertanyaan yang patut untuk direnungkan dan sekaligus menjadi otokritik bagi pandangan sebagian kita selama ini terkait implementasi ekonomi Syariah di tengah umat.

\section{Paradigma Penyebab Kerugian Usaha yang Salah}

Sepanjang sejarah, dunia usaha senantiasa dihiasi dengan kisah-kisah unik seputar keuntungan dan kerugian. Dua kenyataan, manis dan pahit, ini selalu bersandingan dan tidak pernah bisa dipisahkan. Kerugian usaha memiliki banyak faktor penyebab, dimulai dari kesalahan manusia, musibah, atau mesin hingga lingkungan.

\footnotetext{
${ }^{8}$ HR. Bukhari dan Muslim.
} 
Dalam konsep Islam, dimana ekonomi Syariah berjalan di atasnya, kerugian yang dialami manusia, selain karena faktor manusia dan lingkungan, juga dapat diakibatkan oleh dosa para pelaku usaha. Gambaran mudah hubungan antara kerugian dengan dunia usaha, bagaikan seorang pengendara kendaraan dengan berbagai kecelakaan yang ia alami. Ia bisa saja mengalami kecelakaan, karena faktor kesalahannya, kerusakan pada kendaraan, atau kerusakan pada jalan. Tidak jarang pula, kecelakaan terjadi karena murni atas kekuasaan Allah, untuk menguji kadar keimanan pengendara kendaraan.

Oleh karena itu, hendaknya kita merenungkan riwayat berikut. Pada suatu hari, Mush'ab bin Sa'id, dari ayahnya, ia berkata, "Wahai Rasulullah, manusia manakah yang paling berat ujiannya?" Beliau shallallāhu 'alayhi wa sallam menjawab, "Para Nabi, kemudian yang semisalnya dan semisalnya lagi. Seseorang akan diuji sesuai dengan kondisi agamanya. Apabila agamanya begitu kuat (kokoh), maka semakin berat pula ujiannya. Apabila agamanya lemah, maka ia akan diuji sesuai dengan kualitas agamanya. Seorang hamba senantiasa akan mendapatkan cobaan hingga dia berjalan di muka bumi dalam keadaan bersih dari dosa." Dari riwayat ini, kita dapat mengambil pelajaran bahwa kerugian bisa jadi karena kemuliaan kita di sisi Allah Ta’āla.

\footnotetext{
${ }^{9}$ HR. Tirmidzi no. 2398, Ibnu Majah no. 4024, Ad Darimi no. 2783, Ahmad (1/185). Al-Albani dalam Sahīh AtTarghīb wa At-Tarhīb no. 3402 mengatakan bahwa hadits ini sahih.

10 Abubakar Muhammad bin Sirin al-Bashri, lahir 33 H/653-4 M, meninggal $110 \mathrm{H} / 729 \mathrm{M}$, adalah salah seorang tokoh ulama ahli fikih dan perawi hadis dari golongan tabi'in yang menetap di Bashrah. Ibnu Sirin juga terkenal
}

Muhammad bin Sirin ${ }^{10}$ adalah seorang ulama besar yang berprofesi sebagai seorang saudagar. Akan tetapi, pada akhir hayatnya, beliau ditimpa pailit dan terlilit utang sebesar tiga puluh ribu dirham, sehingga beliau pun dipenjara. Beliau baru dapat terbebas dari penjara setelah salah seorang putranya, yang bernama Abdullah, melunasi utangnya. Yang unik dan layak menjadi pelajaran dari kisah beliau, adalah pengakuannya tentang penyebab beliau ditimpa kerugian dan musibah ini. Beliau berkata, "Sesungguhnya, aku tahu penyebab diriku dililit utang, yaitu ucapanku kepada seseorang ketika 40 tahun silam, "Wahai orang pailit..." Tatkala kisah pengakuan ini sampai ke telinga Abu Sulaiman Ad-Darani, ia berkata, "Dosa-dosa mereka itu begitu sedikit, sehingga mereka mengetahui dari mana mereka ditimpa petaka. Sedangkan kita, dosa kita begitu banyak maka tidak heran bila kita tidak tahu, dosa manakah yang menyebabkan kita ditimpa musibah."11

Dari penjelasan di atas, kita mengatakan bahwa sudah sepantasnya bagi para praktisi ekonomi Islam benar-benar menyakini dan mengembalikan urusan rezeki hanya kepada Allah, sehingga kebahagian hidup yang merupakan cita-cita setiap umat Islam dapat tercapai, walau mungkin saja, urusan rezeki mereka terkadang tidak seperti yang diinginkan. Tidak seyogyanya kebahagian dan kedamaian hidup umat Islam digantungkan sepenuhnya dengan

\footnotetext{
kemampuannya dalam menakwilkan mimpi, serta atas kesalehannya. Ibnu Sirin mempelajari ilmu agama serta meriwayatkan hadis antara lain dari Abu Hurairah, Abdullah bin Umar, Abdullah bin Zubair, Imran bin Hushain, dan Anas bin Malik. (https://id.wikipedia.org/wiki/Ibnu_Sirin. Diakses pada tanggal 15 Oktober 2019).

${ }^{11}$ Hilyatul Auliya', 2:271, Abu Nu'aim Al-Ashbahani.
} 
urusan harta benda, akan tetapi hendaknya digantungkan kepada Allah Ta'āla. Bila kita puas dengan karunia Allah maka kebahagiaan hidup pun menjadi milik kita. Rasulullah shallallāhu 'alayhi wa sallam bersabda (artinya), "Sesungsubnya, Allah yang Mabaluas karunia-Nya lagi Mabatinggi akan menguji setiap bamba-Nya dengan rezeki yang telah Ia berikan kepadanya. Barang siapa yang ridha dengan pembagian Allah 'Azza wa Jalla maka Allah akan memberkabi dan melapangkan rezeki tersebut untuknya. Barang siapa yang tidak ridha (tidak puas), niscaya rezekinya tidak akan diberkabi.",12

Sebaliknya,berlari mengejar ambisi dan keserakahan dunia, tidak menjadi jaminan untuk mendapatkan kebahagiaan hidup. Rasulullah shallallāhu 'alayhi wa sallam bersabda (artinya), "Semoga pemuja dinar, dirbam, dan baju sutra (pemuja harta kekayaan, pent.) menjadi sengsara! Bila diberi, ia merasa senang, dan bila tidak diberi, ia menjadi benci. Semoga ia menjadi sengsara dan semakin sengsara (bak jatuh tertimpa tangga pula), dan bila ia tertusuk duri, semoga tiada yang kuasa mencabut duri itu darinya."

Kita mengkhawatirkan jika saja implementasi ekonomi Islam hanya menjadi sebuah model kapitalisme yang dibungkus dengan nilai-nilai religius. Berbeda dengan sistem ekonomi kapitalis, sistem ekonomi Islam sejatinya menetapkan bahwa kepemilikan harta dari segi jumlah (kuantitas) tidak dibatasi namun dibatasi dengan cara-cara tertentu (kualitas) dalam memperoleh harta (ada aturan halal dan haram). Jika kita melihat perkembangan kekuatan negara-negara Muslim di Timur

${ }^{12}$ HR. Imam Ahmad; dinilai sahih oleh Al-Albani.
Tengah, Asia Tenggara, dan Asia Tengah saat ini, modal finansial beberapa negara besar dunia berasal dari eksploitasi minyak, gas bumi, dan bahan-bahan mineral lainnya, sehingga sulit bagi dunia Islam untuk menghindari citra kapitalisme (Quthub, 2015). Oleh karenanya, di antara hal yang dapat dilakukan adalah mengendalikan kapitalisme dengan semangat moral dan etika dan dikombinasikan dengan nilai-nilai keadlilan dari Alquran (Rahman, 2016) dan spiritualitas yang bersumber dari Allah Ta'āla dengan mengacu kepada hukum privat Islam atau hukum Perdata Islam dalam perkara muamalah (Hatta, 2017).

\section{Paradigma Pembelanjaan Harta}

Kita tidak meragukan bahwa metode menghasilkan kekayaan dan keuntungan yang selaras dengan syariat Allah $T a$ 'āla adalah bagian dari prinsip ekonomi Islam. Akan tetapi, itu hanyalah separuh dari syariat Islam dan belum seutuhnya, karena syariat Islam juga mengatur metode pembelanjaan harta kekayaan yang berhasil diperoleh. Bisa saja kita mendapatkan harta kekayaan dari jalur-jalur yang halal, namun karena salah membelanjakannya maka kita pun tidak layak untuk menyandang predikat "ekonom muslim". Predikat "ekonom muslim" hanya dapat disandang oleh orang yang berhasil meraup keuntungan dari jalan-jalan yang halal, dan selanjutnya membelanjakannya dengan cara yang halal dan pada jalan yang halal.

Oleh karenanya, dalam urusan ekonomi, Islam mengajarkan dua

\footnotetext{
${ }^{13}$ HR. Bukhari.
} 
prinsip utama terkait harta, yaitu dari mana didapatkan dan ke mana dibelanjakan. Rasulullah shallallāhu 'alayhi wa sallam (artinya), "Kelak, di hari kiamat, tidaklah kedua kaki setiap hamba dapat bergeser bingga ia mempertanggungjawabkan empat hal: tentang umurnya, untuk urusan apa ia habiskan; ilmunya, amalan yang ia lakukan dengannya; harta kekayaannya, asal-muasal ia mendapatkannya dan pembelanjaan yang dia lakukan dengannya; raganya, untuk urusan apa ia gunakan."

Hadis ini mengantarkan kita kepada satu kesimpulan besar bahwa Ekonomi Islam hanya bisa diterapkan dan dimiliki oleh umat Islam. Dasar dari kesimpulan ini ialah karena orangorang kafir atau negara kafir tidak mungkin mengindahkan syariat Islam dalam hal pembelanjaan harta kekayaan. Dengan demikian, tidak sepantasnya bila umat Islam-dan para pakar ekonomi Islam secara khusushanya mencurahkan perhatian pada metode meraup keuntungan. Sudah saatnya pula, kita menyeru masyarakat Islam secara luas untuk mengindahkan syariat Islam dalam hal pembelanjaan harta kekayaan, khususnya pada aspek atau alokasi yang dapat membawa kemasalahatan umat yang bersifat produktif, bukan untuk keperluan yang hanya bersifat konsumtif.

Hal ini menjadi beralasan mengingat kecenderungan perbankan Syariah yang memudahkan pemberian utang kepada masyarakat. Ketua Majelis Ulama Indonesia (MUI) Bidang Kerukunan Umat Beragama, Yusnar Yusuf, dalam sauatu kesempatan

${ }^{14} \mathrm{HR}$. Tirmidzi; dinilai sebagai hadis sahih oleh Al-Albani dalam kitab Silsilah Al-Ahadits Ash-Shabihah no. 946.

15 https://www.kiblat.net/2016/02/29/mui-bank-syariahmengajarkan-umat-islam-untuk-berhutang/. Diakses pada tanggal 10 Oktober 2019. mengatakan bahwa perbankan syariah telah melakukan promosi besarbesaran untuk mengajak umat Islam berhutang dalam pangsa pasar haji dan umrah. Menurut dia, karena keterbatasan finansial, bank syariah seolah hadir sebagai pahlawan dan mengabaikan bahwa haji dan umrah dikerjakan bagi umat Islam yang mampu, termasuk finansial. Jika bank syariah mempromosikan utang, kata Yusnar, maka tidak ada bedanya dengan bank konvesional. ${ }^{15}$

\section{Minimnya Sumber Daya Insani}

Telah menjadi kodrat umat Islam di negeri kita, bahwa tumbuhnya perbankan syariah yang begitu pesat sejatinya tidak didahului oleh penyiapan sumberdaya insani yang cukup dan andal. Tak ayal lagi, demi memenuhi kebutuhan yang tidak dapat ditunda, menurut Badri $(2016)^{16}$, perbankan syariah menerapkan semboyan kuno "tidak ada rotan akar pun jadi”. Bisa jadi karena karena kebutuhan mendesak, ada bank syariah yang menempuh jalur pintas. Bukan mengkader calon-calon praktisi perbankan syariah melalui lembaga pendidikan yang ada, namun "mengkonversi" praktisi bank konvensional menjadi praktisi perbankan syariah. Dapat kita bayangkan, bagaimana kiranya kondisi perbankan syariah bila ternyata yang memutar roda-rodanya adalah mantan praktisi perbankan konvensional? Wajar, bila pola pikir dan kerja mereka selama aktif di perbankan konvensional masih melekat kuat pada jiwa mereka. Dampak solusi darurat ini adalah

${ }^{16}$ https://pengusahamuslim.com/5689-sektor-riiltantangan-bank-syariah.html. Diakses pada tanggal 10 Oktober 2019. 
perbankan syariah tidak siap untuk terjun ke sektor riil. Alasannya, karena para praktisi perbankan syariah merasa lebih nyaman dengan pola kerja menyerupai pola kerja perbankan konvensional.

Oleh karenanya, untuk melahirkan praktisi-praktisi perbankan syariah yang andal, tentu dibutuhkan lembaga pendidikan yang memadai. Pendidikan ilmu perbankan, lebih-lebih ilmu syariah. Untuk itu, sudah saatnya umat Islam memasukkan sistem ekonomi Islam ke dalam kurikulum sekolah. Dimulai dari tingkat menengah hingga perguruan tinggi. Bahkan tidak ada salahnya bila umat Islam membuka sekolah atau jenjang pendidikan khusus yang mengajarkan syariat Islam dan ekonomi Islam termasuk ilmu-ilmu kaidah Alquran yang mendasarinya (Syaripudin, 2016) secara optimal dan maksimal demi menghasilkan bankir-bankir islami yang bisa membangun perbankan syariah secara meyakinkan.

\section{PENUTUP}

Kesadaran umat Islam akan pentingnya kembali kepada pangkuan agama semakin terasa kuat dan membulat. Salah satunya pada sektor perekonomian dan/atau keuangan Islam. Geliat di sektor ini kemudian memunculkan fenomena ramainya bentuk-bentuk sistem dan model interaksi ekonomi dan keuangan, seperti perbankan syariah, asuransi syariah, pegadaian syariah dan lain sebagainya. Seluruh upaya dan perjuangan sampai pada titik ini merupakan suatu hal yang patut untuk disyukuri. Meski demikian, kekurangan dan kelemahan sistem yang telah ada sebagai sebuah produk ciptaan manusia pasti menyisakan celah dan kekurangan yang patut untuk dikritisi dan diperbaiki. Beberapa hal yang menjadi tantangan yang dihadapi oleh praktik ekonomi syariah Indonesia yang mengakibatkan penerapan ekonomi syariah di Indonesia kurang berkembang sebagai sebuah kriktik adalah :

1. Ekonomi Islam bukan hanya sektor finansial, akan tetapi juga mencakup sektor industri, perdagangan dan berbagai sektor riil lainnya. Para pelaku atau praktisi ekonomi Islam hendaknya segera memusatkan perhatian dan perjuangan mereka pada sektor industri, perniagaan praktis, sektor riil dan yang semisial. Dengan demikian, mereka benar-benar menghasilkan keuntungan dari perniagaan nyata dan bukan dari mempertukarkan uang dengan uang;

2. Penamaan Bank Syariah adalah salah kaprah. Nomenklatur yang lebih tepat bukanlah Bank Syariah akan tetapi Lembaga Keuangan Syariah. Hal ini karena bank bersifat profit oriented murni, sehingga dalam pelaksanaannya bank dituntut untuk selalu menaikkan keuntungan dari waktu ke waktu. Sedangkan pada lembaga keuangan Syariah, orientasi aslinya adalah mengutamakan asas ta'âwun atau berlandaskan prinsip saling tolong menolong diantara sesama yang diutamakan diatas kepentingan mencari keuntungan sejalan dengan ajaran ketuhanan yang dituangkan dalam Alquran dan Hadis;

3. Perhatian para praktisi ekonomi konvensional atau syariah, hingga saat ini, hanya terpusat pada upaya 
mewujudkan $\begin{gathered}\text { keuntungan, } \\ \text { menghindarkan } \\ \text { memeratakan }\end{gathered}$
kesejahteraan. Bahkan, ada yang bermimpi untuk menghapuskan kemiskinan hingga $0 \%$. Impian ini sejatinya bertentangan dengan ketentuan Allah Ta'āla. Banyak praktisi ekonomi Syariah melalaikan hubungan rezeki dengan Allah Ta'ala. Sejatinya, keimanan adalah syarat utama agar suatu sistem atau konsep dapat dinyatakan sebagai "syariat Islam". Para praktisi Ekonomi Islam hari ini sepatutnya menyadari bahwa aktivitas ekonomi seharusnya didasari oleh keimanan kepada Allah Ta'āla;

4. Dalam konsep Islam, dimana ekonomi Syariah berjalan di atasnya, kerugian yang dialami manusia, selain karena faktor manusia dan lingkungan, kerugian usaha juga dapat diakibatkan oleh dosa para pelaku usaha. Oleh karena itu, hendaknya bagi para praktisi ekonomi Islam benarbenar menyakini dan mengembalikan urusan rezeki hanya kepada Allah, sehingga kebahagiaan hidup yang merupakan cita-cita setiap umat Islam dapat tercapai, walau mungkin saja, urusan rezeki mereka terkadang tidak seperti yang diinginkan. Tidak sepantasnya, kebahagian dan kedamaian hidup umat Islam digantungkan sepenuhnya dengan urusan harta benda. Akan tetapi, sepantasnya digantungkan dengan Allah Ta'āla;

5. Kita tidak meragukan bahwa metode menghasilkan kekayaan dan keuntungan yang selaras dengan syariat Allah adalah bagian dari prinsip ekonomi Islam.
Predikat "ekonom muslim" hanya dapat disandang oleh orang yang berhasil meraup keuntungan dari jalan-jalan yang halal, dan selanjutnya membelanjakannya dengan cara yang halal dan pada jalan yang halal. Oleh karenanya, hendaknya umat Islam-dan para pakar ekonomi Islam secara khusus-tidak hanya mencurahkan perhatian pada metode meraup keuntungan. Sudah saatnya pula, kita semua menggalakkan dan menyeru masyarakat Islam secara luas untuk mengindahkan syariat Islam dalam hal pembelanjaan harta kekayaan, khususnya pada aspek atau alokasi yang dapat membawa kemasalahatan umat yang bersifat produktif, bukan untuk keperluan yang hanya bersifat konsumtif;

6. Telah menjadi kodrat umat Islam di negeri kita, bahwa tumbuhnya perbankan syariah yang begitu pesat sejatinya tidak didahului oleh penyiapan sumberdaya insani yang cukup dan andal. Oleh karenanya, untuk melahirkan praktisi-praktisi perbankan syariah yang andal, tentu dibutuhkan pendidikan ilmu perbankan Syariah yang memadai. Untuk itu, sudah saatnya umat Islam memasukkan sistem ekonomi Islam ke dalam kurikulum universitas dan sekolah.

\section{DAFTAR PUSTAKA}

\footnotetext{
Badri, M.A. (2016). Sektor Riil, Tantangan Bank Syariah. https://pengusahamuslim.com/ 5689-sektor-riil-tantangan-banksyariah.html. Diakses pada tanggal 10 Oktober 2019.
} 
Dahlan, A. (2008). Urgensi Studi Ekonomi Islam. Jurnal Pemikiran Alternatif Pendidikan Insania, Vol. 13, No. 1, Jan-Apr, 2008, p. 16129.

Halik, A. (2018). Paradigma Kritik Penelitian Komunikasi (Pendekatan KritisEmansipatoris dan Metode Etnografi Kritis). Jurnal Tabligh, Vol. 19 No. 2, Desember 2018, p.162 - 178 .

Hanurawan, F. (2010). Psikologi Sosial : Suatu Pengantar. Bandung: Rosdakarya.

Hatta, A. (2017). Daya Serap Hukum Islam di Indonesia pada Bidang Privat. Nukbbatul 'Ulum, 3(2), 237-245.

Iskandar, A. (2014). Pengaruh Penerbitan Sukuk Negara Sebagai Pembiayaan Defisit Fiskal dan Kondisi Ekonomi Makro Terhadap Perkembangan Perbankan Syariah di Indonesia Jurnal Info Artha, Vol.II/XII/2014, p. 1-21.

Iskandar, A., Aqbar, K. (2019). Green Economy Indonesia Dalam Perspektif Maqashid Syari'ah. Al-Mashrafiyab: Jurnal Ekonomi, Keuangan, dan Perbankan Syariah, 3(2), p.83-94.

Iskandar, A., Possumah, B. T. (2018). Inklusifitas Keuangan Syariah dan Kemiskinan di Indonesia. Jurnal Nukbbatul 'Ulum, 4(2), p. 1-18.

Mahmuddin, R. (2016). Pengaruh Lafazh Nāṣ al-'Ām (Umum) dan Nāṣ al-Khāṣ (Khusus) pada Ijtihād Para Ulama. Nukbbatul 'Ulum, 2(2), 176-184.

Otoritas Jasa Keuangan. (2019). Statistik Perbankan Syariah, Juli, 2019.

https://ojk.go.id/id/kanal/syari ah/data-dan-statistik/statistikperbankansyariah/Pages/StatistikPerbankan-Syariah---July2019.aspx.

Quthub, M. (2015). Ekonomi Islam atan Kapitalisme Religius, Sebuah Kritik. Impelementasi.

https://www.kompasiana.com/ muhammadquthb/5590c34d957 a61e617a6fb3b/ekonomi-islamatau-kapitalisme-religius-sebuahkritik-impelementasi. Diakses pada tanggal 10 Oktober 2019.

Rahman, R. A. (2016). Konsep Keadilan dalam al-Quran. Nukbbatul 'Ulum, 2(2), 167-175.

Rahmawaty, A. (2007). Ekonomi Syari'ah: Tinjauan Kritis Produk Murabahah dalam Perbankan Syari'ah di Indonesia. Jurnal Ekonomi Islam : La Riba, Vol. 1, No. 2, Desember 2007.

Rusydi, I. (2016). Studi Kritis Terhadap Perbankan Syariah Dalam Praktek Mudharabah. Jurnal Ilmiah Galub Justisi, Vol. 4, No. 1. p.62-75.

Sulaiman, S. (2014). Evaluasi Praktik Murabahah Pada Perbankan Syariah di Indonesia Sebuah Analisis Fiqh. Jurnal Syari'ah, Vol. II, No. II, Oktober 2014.

Syaripudin, A. (2016). Al-Quran sebagai Sumber Agama Islam. Nukbbatul 'Ulum,2(2), 132-139.

Syu'aibun. (2014). Tinjauan Kritis Terhadap Deviasi Akad Murabahah Dalam Aplikasinya Pada Perbankan Syari'ah. Jurnal Human Falah, Vol. 1, No. 2.

Umar, A. I. (2017). Index of Syariah Financial Inclusion in Indonesia. Buletin Ekonomi Moneter dan Perbankan, 20(1), 100126. 